Kong. Res. J. 3(1) : 76-80, 2016

ISSN 2349-2694

Kongunadu Arts and Science College, Coimbatore.

\title{
EVALUATION OF ANTIOXIDANT POTENTIAL OF CASSIA FISTULA (LINN.) BARK EXTRACT
}

\author{
Jeeva, R. and Naganathan Srinath* \\ PG and Research Department of Biotechnology, Kongunadu Arts and Science College Coimbatore. \\ *E.mail: sri7486@gmail.com
}

\begin{abstract}
The agro-climatic and traditional atmosphere of India provides a vital deposit of various herbs available in many parts of the country which are used as traditional medicine in Ayurveda, Unani, Siddha and Homeopathy. The over dosage and irregular practice of consuming various antibiotics has produced many side effects and also helped in evolving multidrug resistant organisms. In this research we have focused on the usage of bark extracts of Cassia fistula (L.) for evaluating their antioxidant scavenging activity. With the traditional practice of shade drying and cold percolation method, the methanolic bark extract was chosen for various antioxidant activity like DPPH, $\mathrm{ABTS}^{+}$, FRAP, Hydrogen peroxide and hydroxyl radical scavenging activity. The plant extract demonstrated higher activity and $\mathrm{IC}_{50}$ value for extract in all the tests showed nearly $60 \mu \mathrm{g} / \mathrm{ml}$. The graphical representation also correlated with the spectrum analysis when plotted using the percentage of inhibition scavenging activity vs the concentration taken for each plant extracts.
\end{abstract}

Keywords: Cassia fistula, DPPH, ABTS+, FRAP, Hydrogen peroxide and hydroxyl radical.

\section{INTRODUCTION}

A country with vital deposit of various herbs growing in the tropical climate like India provides a historical reference and traditional usage of these herbs as food sources, spices and various medicinal preparations from time immemorial. It has been estimated by the World Health Organization (WHO) that nearly $80 \%$ of the world population are dependent on the plant or their extracts which are used in the traditional folk medicine (WHO report, 2009). In this $21^{\text {st }}$ century, the survey shows that with an increase rate of over exposure towards various antibiotics, the evolution of multidrug resistance microbes have increased such as Escherichia coli, Klebsiella pneumoniae, Aeromonas sp., Mycobacterium tuberculosis, M. leprae, Candida sp., etc. (Waters and Basseler, 2005). Due to over growing scenario, the scientists are involved in the process of exploring new drugs either using plant sources like medicinal herbs or their parts or in combination using chemical sources. Wide range of population have made the regular usage of medicinal plants and many are on their path of transition towards the traditional treatment like Ayurveda, Siddha, Unani and Homeopathy to get devoid of the side effects by the usages of chemical drugs.
In the present research, the bark extract of Cassia fistula (L.) has been chosen based on their source and medicinal property recorded in the Ayurvedic texts (Misra and Dixit, 1978; Misra et al., 1997; Perumal Samy et al., 1998; Phongpaichit et al., 2004; Prashanth et al., 2006; Duraipandiyan and Ignacimuthu, 2007; Sangetha et al., 2008). For understanding and evaluating any medicinal plant, the antioxidant potential has to be determined because our body as well as various products which we consume tends to release higher amounts of free radicals (Abraham et al., 1993; Gupta and Ray, 2004; Kumar et al., 2010; Arawwala et al., 2011). These free radicals remain as an adjuvant thereby induces cancer in our body like breast cancer and also various trouble related to gastric problems as well as imbalance in the metabolism. Due to the irregular food habits as well as usage of chemical agents for skin application led us to evaluate the scavenging potential of these plants extracts commonly used in India as a source for treating various skin ailments, allergies and for internal health.

\section{MATERIALS AND METHODS}

\subsection{Collection of herbal plants}

Cassia fistula bark was collected from the areas in and around Coimbatore. The bark was selected based on the appearance and cut into small pieces. The plant barks along with leaves, fruit and flowers were subjected for plant authentication at Botanical Survey of India, Coimbatore, Tamil Nadu. 
2.2. Processing of plant bark using cold percolation method

Based on the method described by Adonizio et al., in 2008, the plant bark was processed using cold percolation method which helps to avoid the medicinal property. The bark pieces were weighed and kept for completed dehydration in dark for a period of 4-6 weeks. They were powdered, sieved and stored in dark bottle. About 3g of powdered plant bark was separately weighed and added to 30 $\mathrm{ml}$ of different solvents in increasing order of polarity such as non-polar solvents (hexane, petroleum ether, chloroform) and polar solvents (ethanol, methanol and distilled water). They were kept in shaking at $120 \mathrm{rpm}$ for 3 consecutive days and the extraction was done using muslin cloth. The filtrate was evaporated in dark, scrapped and stored in dark bottle. They were subjected to antioxidant scavenging activity and based on the results they were used for future research against pathogens.

2.3. Evaluating the various antioxidant properties of extracted Cassia fistula (L.) by in vitro free radical scavenging activity

\subsubsection{DPPH scavenging activity}

Based on the method described by Blois (1958), the scavenging activity of C. fistula was determined by using 2,2-diphenyl-1picryl hydrazyl (DPPH) method. The sample was distributed in various concentrations and as standard Vitamin $\mathrm{C}$ was used. The volume was adjusted to $500 \mu \mathrm{l}$ by adding methanol. $5 \mathrm{ml}$ of $0.1 \mathrm{mM}$ methanolic solution of DPPH was added to these test tubes and vortexed. The tubes were allowed to stand at room temperature for $20 \mathrm{~min}$. The control was prepared as above without any extract and methanol was used for the baseline correction. Changes in the absorbance of the samples were measured at 517 $\mathrm{nm}$. The percentage of inhibition radical scavenging activity was measured by subtracting the values of sample from the control and divided by the values of the control and also taking the percentage for evaluation. The percentage inhibition vs. concentration was plotted and the concentration required for $50 \%$ inhibition of radicals was expressed as $\mathrm{IC}_{50}$ value.

\subsubsection{ABTS ${ }^{+}$radical scavenging activity}

Using the method described by Re et al. (1999), the test was based on the relative activity of antioxidants to quench the radical cation $\mathrm{ABTS}^{+}$. The reaction was initiated by the addition of $1.0 \mathrm{ml}$ of diluted ABTS to $10 \mu \mathrm{l}$ of different concentration of bark extract wit higher activities against the pathogen or $10 \mu \mathrm{l}$ of methanol serve as control. The absorbance was read at $734 \mathrm{~nm}$ and the percentage inhibition was calculated by subtracting the values of sample from the control and divided by the values of the control and also taking the percentage for evaluation.

\subsubsection{Hydrogen peroxide scavenging activity}

Based on the spectrophotometry analysis with a decrease in the absorbance at $230 \mathrm{~nm}$, the hydrogen peroxide scavenging activity was measured using the method described by Ruch et al., 1989. A solution of $\mathrm{H}_{2} \mathrm{O}_{2}$ was prepared in phosphate buffer. $\mathrm{H}_{2} \mathrm{O}_{2}$ concentration was determined using spectrophotometer from its absorption at $230 \mathrm{~nm}$. Various concentrations of plant extracts were added to $\mathrm{H}_{2} \mathrm{O}_{2}$ and incubated for $10 \mathrm{~min}$. The absorbance at $230 \mathrm{~nm}$ was determined against a blank containing phosphate buffer without $\mathrm{H}_{2} \mathrm{O}_{2}$. The percentage of scavenging of $\mathrm{H}_{2} \mathrm{O}_{2}$ and standard compound Vitamin $\mathrm{C}$ was calculated using the formula as mentioned earlier.

\subsubsection{Hydroxyl radical scavenging activity}

The scavenging activity of the plant extracts were determined using the method described by Klein et al., (1991) by taking hydroxyl radicals which were generated from ferrous ammonium sulphate and EDTA. Various concentration of plant extracts were added with $1 \mathrm{ml}$ of iron-EDTA solution $(0.13 \%$ ferrous ammonium sulphate and $0.26 \%$ EDTA), 0.5 $\mathrm{ml}$ of EDTA solution $(0.018 \%)$, and $1 \mathrm{ml}$ of DMSO $(0.85 \% \mathrm{v} / \mathrm{v}$ in $0.1 \mathrm{M}$ phosphate buffer, $\mathrm{pH} 7.4)$. The reaction was initiated by adding $0.5 \mathrm{ml}$ of ascorbic acid $(0.22 \%)$ and incubated at $80-90^{\circ} \mathrm{C}$ for 15 minutes in a water bath. After incubation the reaction was terminated by the addition of $1 \mathrm{ml}$ of ice-cold tri-chloro acetic acid (TCA) $(17.5 \% \mathrm{w} / \mathrm{v}) .3$ $\mathrm{ml}$ of Nash reagent was added and left at room temperature for 15 minutes. The reaction mixture without sample was used as control. The intensity of the color formed was measured spectrophotometrically at $412 \mathrm{~nm}$ against reagent blank. The percentage of hydroxyl radical scavenging activity is calculated by the same formula which was used in previous activity.

\subsubsection{Ferric reducing antioxidant power (FRAP) assay}

Using the method described by Benzie and Strain (1996), the total antioxidant potential of sample was determined using ferric reducing antioxidant power (FRAP) method. The stock solution of $10 \mathrm{mM} \mathrm{2,} \mathrm{4,} \mathrm{6-tripyridyl-s-triazine} \mathrm{(TPTZ)}$ 
in $40 \mathrm{mM} \mathrm{HCl}, 20 \mathrm{~mm} \mathrm{FeCl}_{3}, 6 \mathrm{H}_{2} \mathrm{O}$ and $0.3 \mathrm{M}$ acetate buffer ( $\mathrm{pH}$ 3.6) were prepared. The FRAP reagent contained $2.5 \mathrm{ml}$ TPTZ solution, $2.5 \mathrm{ml}$ ferric chloride solution and $25 \mathrm{ml}$ acetate buffer. It was freshly prepared and warmed to $37^{\circ} \mathrm{C} .900 \mu \mathrm{FRAP}$ reagent were mixed with $90 \mu \mathrm{l}$ water and $30 \mu \mathrm{l}$ test sample/ ethanol /distilled water/ standard antioxidant solution. The reaction mixture was then incubated at $37^{\circ} \mathrm{C}$ for $30 \mathrm{~min}$ and the absorbance was recorded at $595 \mathrm{~nm}$. An intense blue color complex were formed when ferric tripyridyl triazine ( $\mathrm{Fe}^{3+}$-TPTZ) complex were reduced to ferrous $\left(\mathrm{Fe}^{2+}\right)$ form. The absorption at $540 \mathrm{~nm}$ was recorded. The calibration curve was plotted with absorbance at $595 \mathrm{~nm}$ vs concentration of ferrous sulphate in the range $0.1 \mathrm{mM}$ ethanol solutions. The concentrations of $\mathrm{FeSO}_{4}$ were in turn plotted against concentration of standard antioxidants.

$$
\text { Percentage of FRAP scavenging activity }=\frac{\text { Control }- \text { Sample }}{\text { Control }} \text { X100 }
$$

\section{RESULTS AND DISCUSSION}

The collected Cassia fistula (L.) barks were taken to Botanical Survey of India, Coimbatore and authentication no. for the plant is BSI/SRC/5/23/2013-14/Tech./1814. The processing and extraction of the plants bark were done accordingly and the methanolic extract of both the plants were subjected for further scavenging activity analysis based on the work done by Gupta and Ray (2004).

Methanolic extracts of $C$. fistula (L.) were carried out with different antioxidant scavenging activity and observed that the free radical of the extract were found to have high percentage of inhibition against DPPH, $\mathrm{ABTS}^{+}$, hydrogen peroxide, hydroxyl and FRAP. Vitamin C served as the standard for all the antioxidant assays and when compared with the methanolic extracts of $C$. fistula (L.), it has been determined that the bark extract of this plant has higher scavenging activity than the control. The results were observed with higher percentage of inhibition for the extracts (as shown in table 1, 2, 3, 4 and 5) and the $\mathrm{IC}_{50}$ value was observed as $60 \mu \mathrm{g} / \mathrm{ml}$ in all the tests (figure 1, 2, 3, 4, and 5).

This shows that $C$. fistula (L.) has higher scavenging activity as compared with the results of Gupta and Ray, in 2004 and Kumar et al., 2010. Based on the similar experimental outcome of Ahmad and Aqil (2007), the antioxidant activities of the bark extract of $C$. fistula (L.) showed the majority of the active compounds such as phenolics, vitamin
C, vitamin E, tannins and carotenes. Antioxidant activities were measured using FRAP, DPPH, superoxide anion, nitric oxide and hydroxyl radical scavenging assays was also found to higher as the result obtained in the current research.

Table 1. DPPH radical scavenging activity

\begin{tabular}{|c|c|c|}
\hline $\begin{array}{c}\text { Conmontrotion } \\
\text { } 10 / \mathrm{mI}\end{array}$ & $\begin{array}{c}\text { \% of } \\
\text { Inhibition of } \\
\text { Standard }\end{array}$ & $\begin{array}{c}\% \text { of } \\
\text { Inhibition of } \\
\text { Sample }\end{array}$ \\
\hline 20 & 17.69 & 8.88 \\
\hline 40 & 28.31 & 27.84 \\
\hline 60 & 45.09 & 40.11 \\
\hline 80 & 56.21 & 58.88 \\
\hline 100 & 75.22 & 85.82 \\
\hline
\end{tabular}

Table 2. $\mathrm{ABTS}^{+}$radical scavenging activity

\begin{tabular}{ccc}
\hline $\begin{array}{c}\text { Concentration } \\
\boldsymbol{\mu g} / \mathbf{m L}\end{array}$ & $\begin{array}{c}\text { \% of } \\
\text { Inhibition of } \\
\text { Standard }\end{array}$ & $\begin{array}{c}\text { \% of } \\
\text { Inhibition of } \\
\text { Sample }\end{array}$ \\
\hline 20 & 11.17 & 7.28 \\
40 & 27.27 & 35.76 \\
60 & 52.45 & 53.96 \\
80 & 61.17 & 76.55 \\
100 & 69.65 & 89.18 \\
\hline
\end{tabular}

Table 3. Hydroxyl radical scavenging activity

\begin{tabular}{ccc}
\hline $\begin{array}{c}\text { Concentration } \\
\boldsymbol{\mu g} / \mathbf{m L}\end{array}$ & $\begin{array}{c}\text { \% of } \\
\text { Inhibition of } \\
\text { Standard }\end{array}$ & $\begin{array}{c}\text { \% of } \\
\text { Inhibition of } \\
\text { Sample }\end{array}$ \\
\hline 20 & 7.11 & 6.21 \\
40 & 17.22 & 23.28 \\
60 & 36.28 & 57.40 \\
80 & 54.42 & 79.76 \\
100 & 77.49 & 89.68 \\
\hline
\end{tabular}

Table 4. Hydrogen peroxide scavenging activity

\begin{tabular}{ccc}
\hline $\begin{array}{c}\text { Concentration } \\
\boldsymbol{\mu g} / \mathbf{m L}\end{array}$ & $\begin{array}{c}\text { \% of } \\
\text { Inhibition of } \\
\text { Standard }\end{array}$ & $\begin{array}{c}\text { \% of } \\
\text { Inhibition of } \\
\text { Sample }\end{array}$ \\
\hline 20 & 20.44 & 16.93 \\
40 & 39.65 & 31.42 \\
60 & 58.61 & 45.26 \\
80 & 67.02 & 58.10 \\
100 & 74.19 & 78.68 \\
\hline
\end{tabular}

Table 5. Ferric Reducing Antioxidant Power Assay

\begin{tabular}{lll}
\hline $\begin{array}{l}\text { Concentration } \\
\mu \mathrm{g} / \mathrm{mL}\end{array}$ & $\begin{array}{l}\text { \% of Inhibition } \\
\text { of Standard }\end{array}$ & $\begin{array}{l}\text { \% of Inhibition } \\
\text { of Sample }\end{array}$ \\
\hline 20 & 22.3 & 18.0 \\
40 & 40.0 & 36.2 \\
60 & 59.0 & 62.0 \\
80 & 67.3 & 71.3 \\
100 & 74.5 & 96.0 \\
\hline
\end{tabular}


Figure 1. DPPH radical scavenging activity of Cassia fistula (L.) bark extract

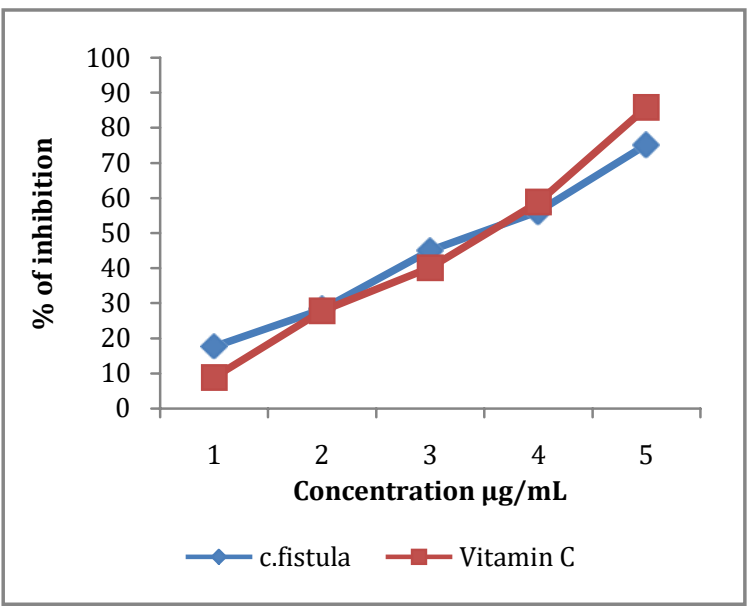

Figure 2. $\mathrm{ABTS}^{+}$radical scavenging activity of Cassia fistula (L.) bark extract

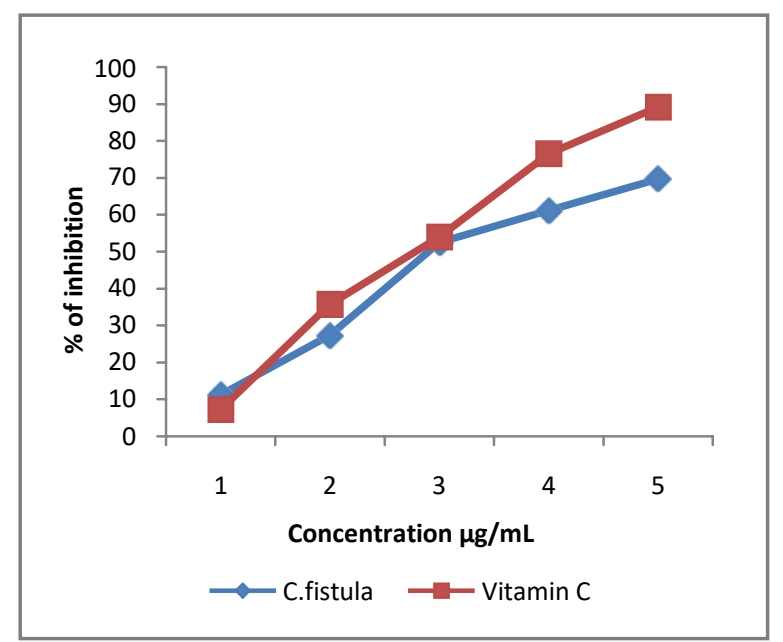

Figure 3. Hydroxyl radical scavenging activity of Cassia fistula (L.) bark extract

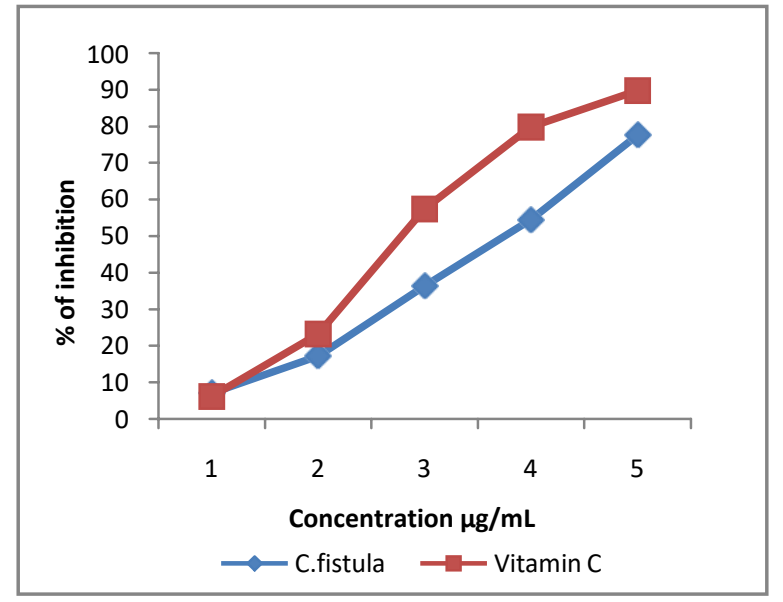

Figure 4. Hydrogen Peroxide radical scavenging activity of Cassia fistula (L.) bark extract

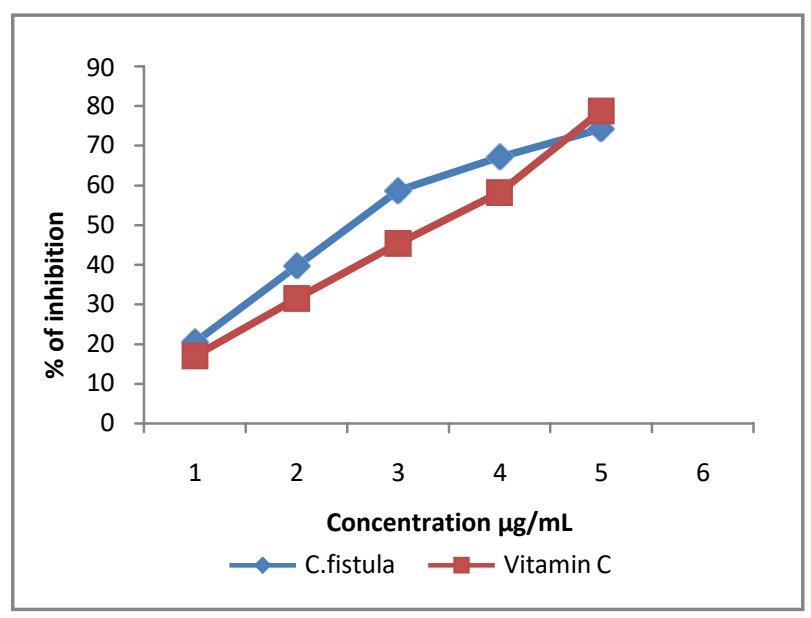

Figure 5. FRAP radical scavenging activity of Cassia fistula (L.) bark extract

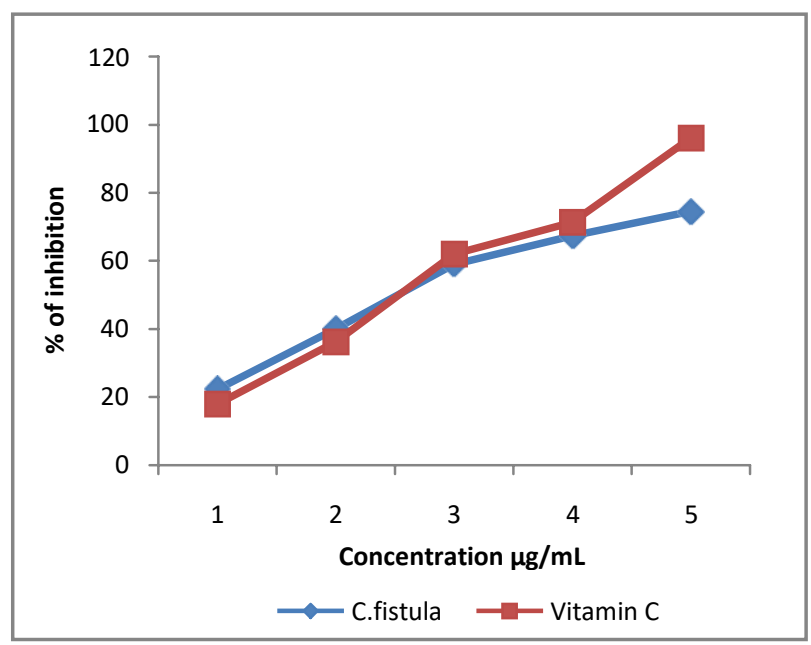

\section{CONCLUSION}

This proves that the plant Cassia fistula (L.) has a higher scavenging activity using the methanolic extract of plant bark. This shows that these plant extracts can be further studied in future to understand the antibacterial activity as well as can serve as a potent drug in future pharmaceutical research.

\section{ACKNOWLEDGEMENT}

We thank our management, Kongunadu Arts and Science College, for its infrastructure and laboratory support for this research work. 


\section{REFERENCES}

Abraham Rubinstein, Kakunda Angel and Kohen Ron, (1993). Protection of the rat jejunal mucosa against oxidative injury by cationized superoxide dismutase. J. Pharm. Sci. 82(12):1285-1287.

Adonizio Allison, Kok-Fai Kong and Mathee Kalai, (2008). Inhibition of quorum sensingcontrolled virulence factor production in Pseudomonas aeruginosa by South Florida plant extracts. Antimicro. Agents Chemother. 52(1):198-203.

Ahmad, I., and F. Aqil, (2007). In vitro efficacy of bioactive extracts of 15 medicinal plants against ESbL-producing multidrug-resistant enteric bacteria. Microbiol. Res. 162: 264-275.

Arawwala, M., I. Thabrew, L. Arambewela and S. Handunnetti, (2010). Anti-inflammatory activity of Trichosanthese cucumerina Linn. in rats. J. Ethanopharmacol. 131:538-543.

Benzie, I. F. F. and J. J. Strain, (1996). Ferric reducing ability of plasma (FRAP) as a measure of antioxidant power: The FRAP assay. Anal. Biochem. 239: 70-76.

Blois, M.S., (1958). Antioxidant determinations by the use of stable free radical. Nature. 1:11992000.

Duraipandiyan, V., and S. Ignacimuthu, (2007). Antibacterial and antifungal activity of Cassia fistula L. An ethnomedicinal plant. J. Ethnopharmacol. 112: 590-594.

Gupta, P.C., and C.S. Ray (2004). Epidemiology of betel quid usage. Ann. Acad. Med. 33(4):31-36.

Klein, S.M., G. Cohen and A.I. Cederbaum (1991). Production of formaldehyde during metabolism of dimethyl sulphoxide by hydroxyl radical radical generating system. Biochem. 20: 60066012 .

Kumar, A., B.R. Garg, G. Rajput, D. Chandel, A. Muwalia, I. Bala and Singh Sumeer, (2010). Antibacterial activity and quantitative determination of protein from leaf of Datura stramonium and Piper betle plants. Pharmacophore. 1(3):184-195.

Misra, S.B., and S.N. Dixit, (1978). Antifungal properties of leaf extract of Ranunculus sceleratus. L. Experientia. 34: 1442-1443.

Misra, T.R., S.R. Singh, H.S. Pandey and B.K. Singh, (1997). A new diterpene from Cassia fistula pods. Fitoterapia. 58: 375-377.

Perumal Samy, R., S. Ignacimuthu and A. Sen, (1998). Screening of 34 medicinal plants for antibacterial properties. J. Ethnopharmacol. 62: 173-182.

Phongpaichit, S., N. Pujenjob, V. Rukachaisirkul and M. Ongsakul, (2004). Antifungal activity from leaf extracts of Cassia alata L., Cassia fistula L. and Cassia tora L. Songklanakarin. J. Sci. Tech. 26: 741-748.

Prashanth Kumar, V., N.S. Chauhan, H. Padh and M. Rajani, (2006). Search for antibacterial antifungal agents from selected Indian medicinal plants. J. Ethnopharmacol. 107: 182188.

Re, R., N. Pelligrini, A. Proteggeenate, M. Yang and C. Rice-Evans, (1999). Antioxidants activity of applying an improved ABTS radical cation decolorisation assay. Free Radic. Biol. Med. 26: 1231-1237.

Ruch, R., S. Cheng and J. Klauning, (1989). Prevention of cytoxicity and inhibition of intercellular communication antioxidant catechins isolated from Chinese green tea. Carcinogenesis. 10: 1003-1008.

Sangetha, S.N, Z. Zuraini, S. Sasidharan and S. Suryani, (2008). Antimicrobial activities of Cassia surattensis and Cassia fistula. J. Mol. Biol. Biotech. 1:1-4.

Waters, C.M. and B.L. Bassler, (2005). Quorum sensing: cell-to-cell communication in bacteria. Annu. Rev.Cell Dev. Biol. 21: 319-346.

WHO survey (2009). In medicinal plants (Eds. Haq. I.) Hamdard Foundation Press, Karachi, 13. 